\title{
Eyal Poleg
}

\section{Memory, Performance, and Change: The Psalms' Layout in Late Medieval and Early Modern Bibles}

\section{Introduction}

The Psalms are a foreign element within the Bible. ${ }^{1}$ Their poetry stands against the prose of other biblical books; their archaic vocabulary and imagery, narrating the prayers of the sinner or referring to an anthropomorphic deity, is sometimes at odds with monotheistic worship and diverges from the tone of historical narrative, prevalent across both Old and New Testament. Rather than hindering their reception, the Psalms' idiosyncrasies have contributed to their overwhelming popularity. Their detachment from biblical history and their personal voice have enabled men and women to relate to them and to embed them into their own prayers. They became the cornerstone of divine worship, and accommodated the devotions of Jews and Christians, monks and nuns, Lutherans and Calvinists.

As Jews and Christians have been performing and meditating on the Psalms for over two millennia, the layout of their books has undergone major transformations. Based on extensive research, this article follows the evolution of biblical books in England for over four centuries. Across the rise of moveable-type print and Reformation, it unfolds how manuscripts and printed books have mediated the biblical text through choice of script and ink, illumination and size. Such features are indicative of the theological stance of editors and stationers, while aiming to accommodate diverse audiences. The Psalms are an outstanding testcase for such an investigation. No other biblical book has been engaged with so ardently and for such differing goals. The Psalms were heavily glossed by scholars and exegetes, punctuated lives in medieval monasteries and nunneries, and were chanted by lay men and women in homes and workshops. The complexity of their structure has led editors and stationers to decide on what to highlight, to marginalise, or to omit altogether, shedding light on their priorities and worldviews.

1 Psalm numbers are presented in the Vulgate (Septuagint) and Hebrew sequences in the following format: Vulgate/Hebrew; Middle- and early modern English quotations have been modernized. 
Monastic Psalters, lay Books of Hours and Primers, and the late sixteenthcentury Whole Book of Psalmes, were all among the most popular books of the Middle Ages and early modernity. In order to efficiently assess the uniqueness of the Psalms' layout and minor variants to their appearance, these books are used only as auxiliary evidence in this essay. Rather, it explores how the Book of Psalms was embedded into full Bibles, a corpus which supports comparison between the Psalms' layout and that of other biblical texts. The introduction sets the scene by briefly charting the Psalms' appearance from the Dead Sea Scrolls to the High Middle Ages, enumerating a number of unique features related to the materiality of the Psalms which will be explored throughout the essay. The essay then explores the rise of the single-volume Bible at the beginning of the thirteenth century, with the Psalms being a major exception to its standardised layout. In Wycliffite Bibles, the first full translation of the Bible into English, the Psalms emerge as sites of competing mnemonics, evidencing the gap between heretical origins and a more orthodox reception. Bible production resumed in England only towards the end of Henry VIII's reign. The layout of the period's Bibles reveals a turbulent break from Rome, when the impact of Church reformers collided with Henry's unease with lay access to Scripture. The last section follows Bibles of more reformed reigns: the new liturgy ushered at the reign of Edward VI and the two seemingly opposing Bibles printed during Elizabeth I's reign. The conclusion reveals a new phenomenon across four centuries, unfolding the dynamics of reform and conservatism which shaped the layout of late medieval and early modern Psalters.

Books of Psalms are among the earliest witnesses to the Hebrew Bible. They take a prominent place among the Dead Sea Scrolls. As the analysis of Anna Krauß and Friederike Schücking-Jungblut in the current volume demonstrates, even these early samples present the Psalms in a layout distinct from other biblical books. ${ }^{2}$ While the majority of biblical texts are written as continuous texts, the Psalms are gradually depicted in lines of meaning, at times further divided into stichs. This followed their poetical structure, in which each verse comprises of a distinct unit, and grew to be depicted as such in biblical manuscripts. The earliest evidence reveals a link between performance, contents and layout as the novel layout was first applied to Psalm 118/19, whose "reading or reciting [...] is a meditative exercise of praying". ${ }^{3}$

2 See Chapter 1 in the present volume: Anna Krauß and Friederike Schücking-Jungblut, "Stichographic Layout in the Dead Sea Psalms Scrolls: Observations on Its Development and Its Potential."

3 Krauß and Schücking-Jungblut, "Stichographic Layout," 23. 
The superscriptions (also known as superscripts or tituli) are short verses affixed to individual Psalms, and are arguably the least stable feature of the Book of Psalms. Whereas the Psalms are typically a-historical devotional hymns, the superscriptions identify specific moments in biblical history, Temple worship or Israelite literature. Their connection to the text of the Psalms is at times tenuous, and their language enigmatic. There is evidence to suggest that already in the second century BC the translators of the Septuagint had found their vocabulary challenging; their position in the Dead Sea Scrolls is unclear, and biblical scholars nowadays debate their dating and function. ${ }^{4}$ The superscriptions have remained a distinct textual unit from inception to the present day. They are often separated from the body of the Psalm by diverse means and to the best of my knowledge have not been chanted in Jewish or Christian worship. In many liturgical manuscripts, therefore, the superscriptions are omitted. The Psalms are commonly identified, in Jewish and Christian sources alike, by their opening line following the superscriptions.

The Psalms attracted and challenged emerging Christian communities in Late Antiquity. As Christians embraced the Psalms as the foundation of divine worship, they developed means of accommodating them to new dogma. Church Fathers employed allegorical and Christological exegesis in linking the Psalms to events from the life of Christ, as well as from Church or salvation history. ${ }^{5}$ Mirroring Jewish practice, the Psalms became the cornerstone of church liturgy, influencing their layout in medieval manuscripts. ${ }^{6}$ Much like earlier Hebrew manu-

4 Lesley McFall, “The Evidence for a Logical Arrangement of the Psalter," Westminster Theological Journal 62 (2000): 223-56, with a bibliography of previous scholarship; Sam Mirelman, "Contrafactum in the Ancient near East," in Herausforderungen Und Ziele Der Musikarchäologie: VorträGe Des 5. Symposiums Der Internationalen Studiengruppe Musikarchäologie Im Ethnologischen Museum Der Staatlichen Museen Zu Berlin, 19.-23. September $2006=$ Challenges and Objectives in Music Archaeology: Papers from the 5th Symposium of the International Study Group on Music Archaeology at the Ethnological Museum, State Museums Berlin, 19-23 September 2006, ed. A.A. Both, et al. (Rahden/Westfalen: M. Leidorf, 2008): 99-110.

5 In manuscripts from the early and high Middle Ages these took the form of Tituli (or titles), short verses which summarized exegetical works to replace the superscriptions in prefacing the Psalms with means of connecting them to established dogma. See: Pierre Salmon, Les "Tituli Psalmorum” Des Manuscrits Latins, Collectanea Biblica Latina (Roma: Abbaye Saint-Jérome, 1959).

6 Paul Saenger, "The Impact of the Early Printed Page on the Reading of the Bible," in The Bible as Book: The First Printed Editions, ed. Paul Saenger and Kimberly Van Kampen (London: British Library in association with The Scriptorium: Center for Christian Antiquities, 1999): 31-51; A useful introduction to the structure of medieval Psalters is Elizabeth Solopova, Latin Liturgical Psalters in the Bodleian Library: A Select Catalogue (Oxford: Bodleian Library, University of Oxford, 2013). 
scripts, the Psalms were typically written in lines of poetry. In earlier manuscripts they were written in lines of meaning, spaciously representing their poetical structure, and the way they were chanted in churches. In later manuscripts scribes adopted a less parchment-wasteful layout. They marked the beginning of each verse with a minor capital, which, by the thirteenth century, was often in alternating red and blue initials (Fig. 1). A puctus elevatus (inverted semicolon) separated the stichs. This layout accorded with the performance of the Psalms: they were often chanted with each verse as an independent unit, followed by a short doxology; a distinct pause followed each stich, and was discussed in liturgical and musical commentaries. ${ }^{7}$ Like other liturgical texts, the Psalms were known by their incipit, or their opening line in the Vulgate text (omitting the superscription). Thus, the first Psalm was known as Beatus vir ("Blessed is the man"), the second Quare turbabuntur gentes ("Why have the Gentiles raged") and so forth. The entire book of Psalms was chanted by monks and nuns in weekly or bi-weekly cycles. To facilitate this, key Psalms were signalled-out in medieval manuscripts. ${ }^{8}$ In the high and later Middle Ages historiated initials were deployed to identify these Psalms, often depicting the Christological interpretation of the Psalms, or alluding to their liturgical performance. Thus, for example, the initial to Psalm 110/11 ("The Lord said to my lord: sit thou on my right") often depicts the Trinity, while that to Psalm 97/8 ("O sing unto the Lord"), commonly depicts monks in the course of chanting the Psalms (Fig. 1).

\section{The Later Middle Ages}

In the early Middle Ages, very few libraries possessed a full Bible, and single-volume Bibles (known as pandects) were a rarity. Bible were typically a multi-volume affair: heavy, expensive, and befitting the libraries of large and well-endowed religious establishments, or the wealthy aristocracy. This situation underwent a radical transformation in the first three decades of the thirteenth century. Then, the creation of new universities joined with a rising lay book-trade and the establishment of the mendicant orders (primarily the Franciscans and the Dominicans) to bring

\footnotetext{
7 S.J.P. van Dijk, "Medieval Terminology and Methods of Psalm Singing," Musica Disciplina 6 (1952): 7-26; John Harper, The Forms and Orders of Western Liturgy from the Tenth to the Eighteenth Century: A Historical Introduction and Guide for Students and Musicians (Oxford: Clarendon Press, 1991), 67-72.

8 This was commonly a seven-fold division, with Psalm 1 the first Psalm on Matins on Sundays, Psalm 26/7 on Mondays, Psalm 38/9 on Tuesdays, etc.
} 


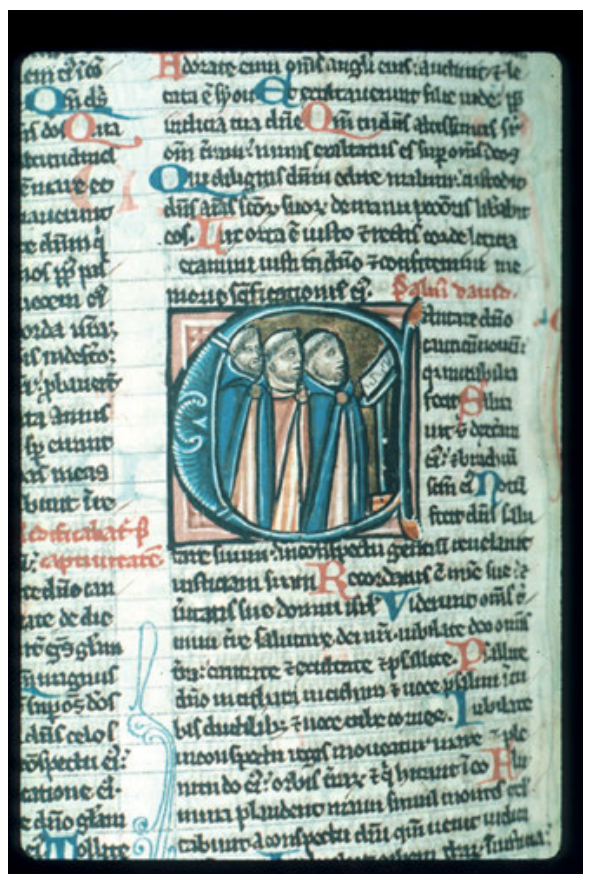

Fig. 1: Cantate Domino - initial to Psalm 110/11 in the de Brailes Bible. Oxford, Bodleian Library, MS Lat. Bib. E. 7, fol. 191v. By permission of The Bodleian Library, University of Oxford.

about the production and dissemination of single-volume, small and portable Bibles. ${ }^{9}$ By 1250, pandects became the norm across medieval Europe. Although copied laboriously by hand, these often-minute volumes (with many measuring less than $20 \mathrm{~cm}$ in length) adhered to a uniform layout, and as such should be seen against the backdrop of the late medieval mass-communication revolution. ${ }^{10}$ The proliferation of pandects was accompanied by the introduction of a highly efficient navigation and retrieval system, encoded in a layout of great longevity, which has influenced the appearance of Bibles ever since. A typical example is seen in Fig. 2, in which running titles in red and blue identify the biblical book. The biblical text is written in two columns, and divided into numerical chapter divisions. These chapter divisions were the hallmark of the Late Medieval Bible (LMB), and are still

9 Eyal Poleg and Laura Light, eds., Form and Function in the Late Medieval Bible, WWMW (Leiden: Brill, 2013).

10 David d'Avray, "Printing, Mass Communication and Religious Reformation: The Middle Ages and After," in The Uses of Script and Print, 1300-1700, ed. Julia C. Crick and Alexandra Walsham (Cambridge: Cambridge University Press, 2004): 50-70. 


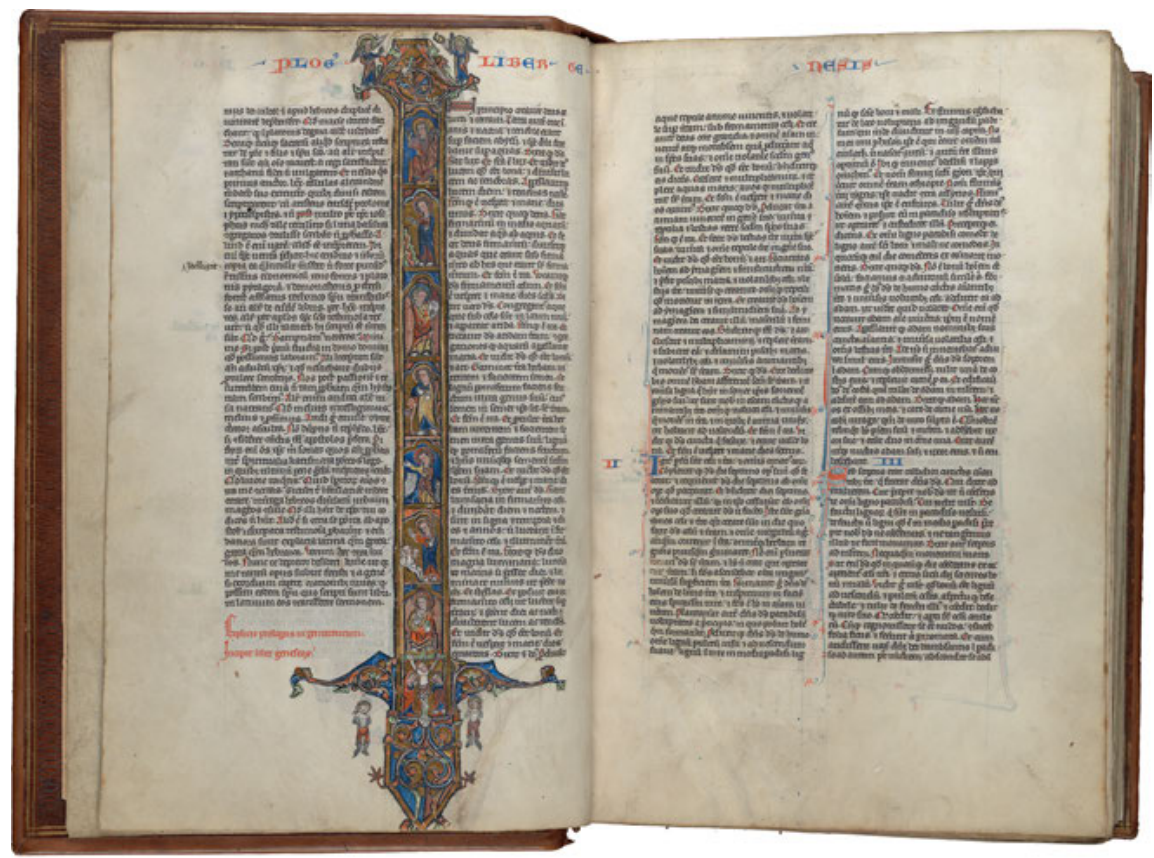

Fig. 2: Late Medieval Bible Layout - Opening of Genesis, Edinburgh University Library MS 2, fols $3 v-4 r$. Edinburgh University Library Special Collections.

employed (with minor variation) in Bibles nowadays. (Verse division was introduced to Bibles only in the sixteenth century.)

The new pandects became an immediate success. They emerged from centres of learning in Northern France, South-East England and Northern Italy, to spread rapidly throughout Europe. Their uniform layout is witnessed nowadays in hundreds of manuscripts. The uniformity of the layout did not apply, however, to all biblical books. The Psalms were the most notable exception and in the overwhelming majority of LMBs were devoid of the key features of the abovementioned innovative layout. ${ }^{11}$ Like earlier manuscripts, their layout reflected the performance of the liturgy, and the way the Psalms were retained in the memory of the clergy who chanted them day and night, the same clergy who were also the prime audience of the LMB. The Psalms were not subjected to the numerical chapter division, characteristic of other biblical text. Rather, they were still

11 A more in-depth discussion of the Psalms in LMBs is Eyal Poleg, Approaching the Bible in Medieval England, Manchester Medieval Studies (Manchester: Manchester University Press, 2013), 129-38. 
known and identified by their incipit. Major initials were employed to identify key Psalms, while minor initials marked the beginning of each verse in alternating red and blue. The link between performance and the LMB, however, is far from evident. Laura Light has recently explored the use of these Bibles within the liturgy, revealing a small group of Bibles containing Mass-texts, or Bibles used within the Divine Office. ${ }^{12}$ The initial in Fig. 1, however, demonstrates a gap between liturgical ideals and practicalities. The image depicts monks in the course of liturgical chant, following a book open on the lectern. As this initial precedes Psalm 97/8, one can imagine they are singing the Psalms. However, the book containing the image, the c.1250 de Brailes Bible, is a small pocket Bible, and one which would be ill suited for placing on a lectern or reading from afar. It was suitable for facilitating individual worship (the type of worship often suggested in Light's research), while still depicting the ideal of communal Psalmody.

One key element draws us away from seeing the Psalms in LMBs merely as mirroring liturgical rites. In the overwhelming majority of LMBs the Psalms are preceded with superscriptions, which follow Jerome's translation of the biblical superscriptions in the Vulgate (in the Gallican version). At odds with liturgical manuscripts and performance, the superscriptions brought the complex nature of the Psalms to the mind of readers, reminding them of a function beyond chant. The superscriptions were not integrated into the body of the Psalms, but were signalled out and separated from the body of the Psalm, noted in red ink. The superscriptions' integration evidences an interest in the literal sense of Scriptures, and in the Bible's original languages, predating Humanists and Reformers alike. Like the most common addendum to the LMB - a glossary of Hebrew and Aramaic biblical names known as the Interpretations of Hebrew Names - the superscriptions brought to mind elements of Jewish worship and archaic Hebrew vocabulary. They attest to the origins of the LMB among biblical exegetes, who remained one of its prime users.

A small group of LMBs, primarily of mendicant origins, evidences new modes of thinking about the Psalms, as well as about liturgy more widely. ${ }^{13}$ The Psalms emerge in this group as sites of conflicting mnemonics. Their layout replicates that of liturgical manuscripts and earlier Bibles, reflecting the performance of the

12 Laura Light, "Thirteenth-Century Pandects and the Liturgy," in Form and Function in the Late Medieval Bible, ed. Eyal Poleg and Laura Light (Leiden: Brill, 2013): 185-215; Laura Light, "What Was a Bible For? Liturgical Texts in Thirteenth-Century Franciscan and Dominican Bibles," Lusitania Sacra 34 (2016): 165-82.

13 This group is explored in my A Material History of the Bible, England 1200-1553 (Oxford: Oxford University Press, 2020). 
Psalms. They also, however, incorporate the numerical chapter divisions, subjecting the Psalms to the common layout of the LMB, and to a form of knowledge that did not rely on the Psalms' incipits. ${ }^{14}$ This layout accords with the treatise of Hugh of St Victor ( $\$ 1142$ ), who had advocated memorizing the Psalms not as chanted liturgical text, but rather visually, placing them on a numerical grid and thus retaining the ability to recall then out of sequence. ${ }^{15}$ This distinct layout of the Psalms remained an exception among biblical manuscripts, with the majority of Bibles keeping to the more liturgical, and traditional, means of presenting and recalling the Psalms.

The appeal of the Psalms extended beyond Latin Bibles and clerical readership. Nuns and lay brothers, as well as lay men and women, were presented with the Psalms in a variety of ways. First among them were Books of Hours, which simplified monastic liturgy to facilitate lay devotions. ${ }^{16}$ Psalm translations also engaged with new audiences. As explored by Annie Sutherland, the English Psalms have been central to vernacular devotion throughout the Middle Ages. ${ }^{17}$ The Psalms emerge once more as sites of conflicting mnemonics, now with the added difficulty of navigating between English translation and (primarily) Latin performance. Different strategies for presenting and engaging with the Psalms are evident in manuscripts of the Wycliffite Bible - the first translation of the

14 A preliminary list includes: Cambridge, CUL Ee.1.16; Cambridge, Fitzwilliam Museum, McLean 16 (Dominican); Cambridge, Gonville and Caius MS 350/567 (Oxford, second quarter of thirteenth century); Cambridge, Pembroke 303 (Dominican); Cambridge, Trinity B.10.21 (Dominican); Edinburgh, UED MS 313; London, BL Add 35085 (Dominican); London, BL, Add. 31830 (Dominican, Naples c.1253); London, BL, Arundel 303 (Dominican, Oxford); London, BL, Royal MS 1.D.i (Mendicant, Oxford); London, Lambeth 534 (with the Dominicans of Arklow [Ireland] in the fifteenth century); Oxford, Bod., Auct. D.4.11 (Franciscan, Oxford); Oxford, Bod., Auct. D.5.9 (in Lincoln Cathedral by the fourteenth century); Oxford, Bod., Lat. bibl. e. 7 (Dominican, Oxford c.1250); Paris, BnF, MS lat. 163 (Dominican and later Franciscan); San Marino, California, Huntington Library, HM 51.

15 William M. Green, "Hugo of St. Victor: De Tribus Maximis Circumstantiis Gestorum," Speculum 18 (1943): 484-93; Hugh of St. Victor, “The Three Best Memory Aids for Learning History,” in The Medieval Craft of Memory: An Anthology of Texts and Pictures, ed. Mary Carruthers and Jan M. Ziolkowski (Philadelphia: University of Pennsylvania Press, 2002): 32-40; For discussion see Mary Carruthers, The Book of Memory: A Study of Memory in Medieval Culture, CSML (Cambridge: Cambridge University Press, 1992), 121-27.

16 On Books of Hours and their use: Eamon Duffy, Marking the Hours: English People and Their Prayers 1240-1570 (New Haven: Yale University Press, 2006); Kathryn M. Rudy, Piety in Pieces: How Medieval Readers Customized Their Manuscripts (Cambridge: Open Book Publishers, 2016). 17 Annie Sutherland, English Psalms in the Middle Ages, 1300-1450 (Oxford: Oxford University Press, 2015). 
entire Bible into English at the end of the fourteenth century. ${ }^{18}$ The Wycliffite Bible originated among the followers of John Wyclif ( +1384$)$, whose rejection of the established Church had led to the Church condemnation of Wycliffites (or Lollards) as heretics; the centrality they placed on lay access to Scriptures had resulted in Constitutions of Archbishop Arundel in 1407/09, which prohibited unauthorised vernacular translations of Scriptures. The manuscript culture of the Wycliffite Bible, however, presents a different narrative, with survival rates akin to orthodox Bibles on the Continent (ca. 250 manuscripts) and a general lack of heterodox texts in the vast majority of surviving manuscripts.

In Wycliffite Bibles the Psalms by and large replicate the layout of the LMB, with its verse identification and major initials for key liturgical Psalms. This was seen by Anne Hudson as evidence for the gravitational pull exerted by the Book of Psalms, arguing that Wycliffite Bibles "seem [...] to have been unable to escape from the traditional high regard for this book of the Old Testament."19 An in-depth examination of key manuscripts sheds light on how this process took place. Oxford, Bodleian Library MS Bodley 959 is well known among scholars of the Wycliffite Bible. One of its earliest manuscripts, this text has been mined as evidence to the course of the translation project. ${ }^{20}$ Unnoticed by scholars, however, is a moment frozen in the evolution of the Wycliffite Bible. The original scribe of the Psalms had transferred the common layout of the Latin Psalms into the English. He had also noted the Psalms' numbers in the margins in a mixture of Arabic and Roman numerals (as was done with other biblical books). His work was followed by another scribe (a rubricator), who preceded each Psalm with a three-line red capital and noted down the superscriptions in red, reflecting the appearance of the LMB (Fig. 3).

18 On the Wycliffite Bible: Mary Dove, The First English Bible: The Text and Context of the Wycliffite Versions, CSML 66 (Cambridge: Cambridge University Press, 2007); Elizabeth Solopova, ed., The Wycliffite Bible: Origin, History and Interpretation, MRAT (Leiden: Brill, 2016). On its dependency on the Latin Bible: Eyal Poleg, "Wycliffite Bibles as Orthodoxy," in Instructing the Soul, Feeding the Spirit and Awakening the Passion: Cultures of Religious Reading in the Late Middle Ages, ed. Sabrina Corbellini (Turnhout: Brepols, 2013): 71-91; Anne Hudson and Elizabeth Solopova, “The Latin Text," in The Wycliffite Bible: Origin, History and Interpretation, ed. Elizabeth Solopova (Leiden: Brill, 2016): 107-32.

19 Anne Hudson, The Premature Reformation: Wycliffite Texts and Lollard History (Oxford: Oxford University Press, 1988), 182.

20 For short description and summary of bibliography see Elizabeth Solopova, Manuscripts of the Wycliffite Bible in the Bodleian and Oxford College Libraries, Exeter Medieval Texts and Studies (Liverpool: Liverpool University Press, 2016), 88-92. The Psalms in the manuscript have also been central to Sutherland, English Psalms in the Middle Ages, 1300-1450, 112-19; Sutherland, “The Wycliffite Psalms," in The Wycliffite Bible: Origin, History and Interpretation, ed. Elizabeth Solopova (Leiden: Brill, 2016): 183-201 (187-92). 


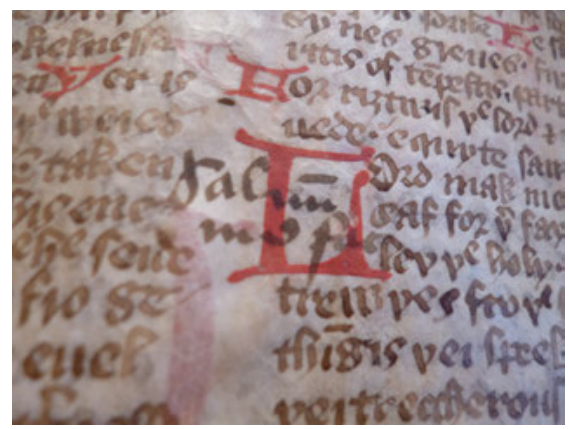

Fig. 3: Psalm layout (detail); Oxford, Bodleian Library MS Bodl. 959. By permission of The Bodleian Library, University of Oxford.

Translating the Psalms into English affected their identification. Recalling the Psalms through their Latin incipit no longer applied to the English Psalter, with its differing opening lines. The original production team had avoided the link with Latin Psalmody altogether, and the Psalm's number became their only means of identification. This, however, was soon to change. Shortly after the scribe and rubricator had concluded their labours, another reader added the Latin incipits as means of Psalm-identification beyond those offered by the original creators. The timing of this addition can be ascertained by a close examination of the manuscript (Fig. 3). The hand of the annotation is contemporaneous with that of the original scribes. Its ink, however, is on top of the capital letter, clearly indicating that this took place after the rubricator had finished his role. The original stage of production thus presented a fully English Psalter, which left little place to Latin mnemonics. The gap between inception and reception was quickly filled, and the manuscript reveals how the Psalms' layout was made to accommodate common mnemonics and Latin chant. A similar phenomenon is evident in Cambridge University Library MS Add. 6681, another manuscript from the earlier strata of the Wycliffite Bible in which an early reader/scribe had provided the Latin incipits.

The omission of the Latin incipit in the earliest strata of the Wycliffite Bible, and its insertion shortly afterwards, is part of a wider phenomenon, evident across the manuscript culture of the Wycliffite Bible. A move away from reformed ideal and heterodoxy and into more orthodox use of the Bible comes to the fore when examining the addenda to the Wycliffite Bible. As explored by Matti Peikola, tables of lections to the Wycliffite Bible, which link biblical readings with a given liturgical feast, gradually aligned with common liturgical use by incorporating non-biblical saints, frowned upon by Wyclif and his followers. ${ }^{21}$ The most overt

21 Matti Peikola, “'First Is Writen a Clause of the Bigynnynge Therof': The Table of Lections in Manuscripts of the Wycliffite Bible," in Form and Function in the Late Medieval Bible, ed. Eyal Poleg and Laura Light (Leiden: Brill, 2013): 351-78. 
link between the translation project and heterodoxy is the General Prologue, a treatise discussing Bible and translation, which opposes the established Church. This treatise, however, exists only in a fraction of Wycliffite Bibles. ${ }^{22}$ The majority of Wycliffite Bibles are therefore devoid of any link to heterodox thought, and their layout, especially that of the Psalms, links them to orthodox, Latin, worship.

The Psalms emerge as a major arena for the forces of heterodoxy and orthodoxy, Latin and English. The multiple layers of the Psalms - text, superscription, incipit, number - forced editors, stationers and readers to omit and highlight, to take a stance on importance and audience. Annie Sutherland's work on medieval English Psalters has highlighted the competing linguistic spheres of Latin and English, and revealed that, across different translations and manuscripts, "incipits are almost universally preserved." ${ }^{23}$ Marked in red, they became one of the most distinct features of the Psalms' layout, and central means in their identification. ${ }^{24}$ The Psalms were recalled performatively, experienced through their chanting in the liturgy. Here I veer from Sutherland's analysis. Sutherland argues that "It is, in fact, no exaggeration to say that the translated psalms formed the backbone of intercessory experience in the late Middle Ages". ${ }^{25}$ The manuscript culture, however, suggests the Psalms were encountered primarily through the Latin of the performed liturgy. Not only in monastic and church worship, but Books of Hours, commonly owned by lay men and women (and overwhelmingly in Latin) attest to the way the Psalms were encountered in the later Middle Ages.

One should not hasten to place a boundary between lay and clerical, Latin and vernacular Psalmody. The layout of the Psalms in Wycliffite Bibles seems to merge, rather than oppose, linguistic spheres. Latin and English cohabitate the space of Wycliffite Psalters, with multiple layers of information - chapter number, Latin incipit, biblical superscription - presented one next to the other. This cohabitation is most evident in a liturgically oriented Psalter, where each verse of the Psalms is preceded with its Latin opening words (Fig. 4). ${ }^{26}$ This manuscript merges Latin and English Psalmody, but did not constitute a bilingual

22 Mary Dove, ed., The Earliest Advocates of the English Bible: The Texts of the Medieval Debate (Exeter: University of Exeter Press, 2010), 3-85; For analysis see Kantik Ghosh, “The Prologues," in The Wycliffite Bible: Origin, History and Interpretation, ed. Elizabeth Solopova (Leiden: Brill, 2016): 162-82.

23 Sutherland, English Psalms in the Middle Ages, 1300-1450, 264.

24 Sutherland's view of red as denoting hierarchy is at odds with the use of red across Latin manuscripts, and especially with the presentation of the Superscription in the LMB.

25 Sutherland, English Psalms in the Middle Ages, 1300-1450, 274.

26 Other Psalters are London, British Library MSS Yates Thompson 52, Add. 10,047, and Add. 31,044 . 


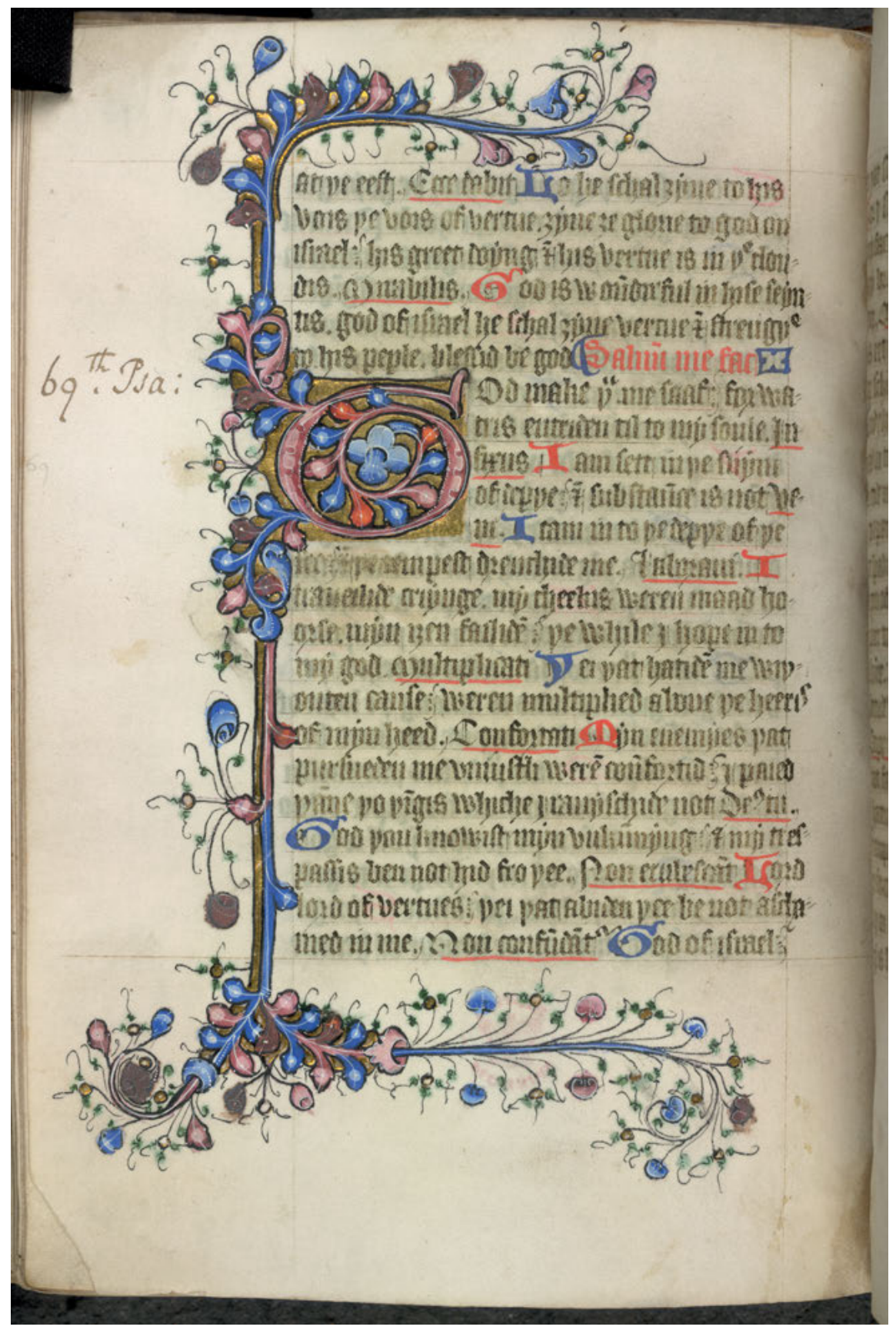

Fig. 4: Wycliffite Psalter (British Library MS Yates Thompson 52, fol. 96v). () The British Library Board. 
Psalter. Rather, it enabled readers to employ the book of Psalms in the course of Latin Psalmody, or alongside a Latin Psalter. It also cued the memory of readers versed in the Latin Psalms to the English translation. Scholars often regard vernacular manuscripts as linked with the laity and Latin illiteracy. Such Psalters, however, were not aimed at the uninitiated. Rather, previous knowledge of Latin Psalter is necessary to decipher the truncated Latin incipits, and their layout suggests these were created for readers embedded within Latin Psalmody.

A glimpse into the function and readership of Wycliffite Psalters is revealed in a few explicit statements made by translators and editors. The General Prologue makes clear that although the Psalter "teaches plainly the mysteries of the Trinity, and of Christ's incarnation, passion, rising again [..] and the coming of the Antichrist [...] and often rehearses the stories of the Old Testament," it was nevertheless most challenging to understand as "No book in the Old Testament is harder to understand to us Latins." ${ }^{27}$ An additional prologue made clear the role of the superscriptions in unfolding the mysteries of the Psalter and its links with biblical history. It argues for a two-tier understanding of the Psalter: the superscriptions mark events from biblical history, while the Psalms themselves are more prophetic, following events from the life of Christ and Church history. The link between Psalms and biblical history was also expanded in other means.

Short glosses are often incorporated into Wycliffite Bibles, placed before individual Psalms to create "mini-prologue", marked-off in red or brown underline. ${ }^{28}$ These build on the superscriptions in connecting the Psalms to the life of David and Jewish history (e.g., the gloss to the second Psalm: "A gloss. The second Psalm that has no title in Hebrew and in Jerome's translation; was made of David as the Apostles witnessed in iiij that of deeds [Acts 4:25]") ${ }^{29}$; they also provide a more allegorical understanding of the Psalter, linking Psalms to the life of Christ and the history of salvation (e.g. Psalm 40, depicting a man who is persecuted and then risen by God, is preceded by "A gloss. This Psalm is expounded of Christ's passion and rising again”; Psalm 95, a song of glory to God who comes to judge the earth, is preceded by "This Psalm has no title, neither in Hebrew nor in Jerome. This Psalm speaks of the time of Christ, that began properly at the beginning of the preaching of the Gospel.”). The glosses helped align Psalms with Christian dogma. They commonly appear in the margins, but at times were integrated into the textual column, merging text and interpretation. They were not noted in the

27 Dove, Earliest Advocates, 58.

28 Dove, First English Bible, 157-59; Michael P. Kuczynski, “Glossing and Glosses,” in The Wycliffite Bible: Origin, History and Interpretation, ed. Elizabeth Solopova (Leiden: Brill, 2016): 346-67; Sutherland, "The Wycliffite Psalms."

29 BL Additional MS 10,046 fol. 5r. 
abovementioned Wycliffite Psalters. In these manuscripts, which befitted liturgical use, superscriptions and glosses were omitted altogether, putting aside means of unfolding the literal sense in favour of liturgical practice.

\section{Henry the Eighth's Bibles}

Bibles were printed on the Continent from the very beginning of moveable-type printing. Gutenberg's celebrated 42-line Bible replicated the appearance of the LMB, albeit on a much grander scale, and most incunabula followed suite. Gradually, however, printers employed new techniques to innovate in size and layout. English printing lagged behind the Continent for much of the period, with books typically shorter and less sophisticated than their Continental counterparts. This, combined with a general unease with vernacular theology following Arundel's fifteenth-century Constitutions, had led to a lack of any printed Bible in England for nearly a century after Gutenberg's innovation..$^{30}$ By the 1530 s, however, the wheels were clearly moving in the direction of an English Bible. Reforming ideals took hold among English scholars, and on the Continent William Tyndale was publishing biblical books to fill his plan of putting an English Bible in the hands of every ploughboy. In England, Henry VIII's active engagement with Christian theology, and complex relationship with the Roman curia, sowed the seeds for a national Bible.

The hesitant beginning of the English Bible came to partial fruition in 1535, with the publication of two Bibles. The first Bible printed in England was in Latin. Ill fitted for histories of the English Reformation, it has received little scholarly attention. ${ }^{31}$ It was printed by Thomas Berthelet, the King's Printer, and the book's "Epistle to the Reader" links the project to Henry himself. However, it was not

30 This lacuna has not been adequately explored. Thus, in a recent volume of The New Cambridge History of the Bible, the chapter on English Bibles begins at 1520, and the lack of English Bibles is only briefly mentioned in Andrew Pettegree, "Publishing in Print: Technology and Trade," in The New Cambridge History of the Bible: Volume 3: From 1450 to 1750, ed. Euan Cameron (Cambridge: Cambridge University Press, 2016): 159-86. For a survey of English printing and its dependence on the Continent: Lotte Hellinga, "Printing," in The Cambridge History of the Book in Britain Volume 3: 1400-1557, ed. Lotte Hellinga and J.B. Trapp (Cambridge: Cambridge University Press, 1999): 65-108.

31 It is presented in Peter W.M. Blayney, The Stationers' Company and the Printers of London 1501-1557, 2 vols. (Cambridge: Cambridge University Press, 2013), 352-56; and discussed at length in Eyal Poleg, "The First Bible Printed in England: A Little Known Witness from Late Henrician England," JEH 67 (2016): 760-80. 
endorsed by Henry, and its modest appearance is far removed from a majestic tome. Attesting to Berthelet's limited capacities, the Bible is a selection of biblical books. The preface promises a second volume, which never saw the light of day, nor, in my eyes, was ever realistically intended. Berthelet's book is comprised of the "best of" the Bible: the Pentateuch, Joshua, Judges, the Psalms, Proverbs, Wisdom and the entire New Testament. This peculiar amalgamation followed Berthelet's Continental models, while according with the gist of salvation history and liturgical performance. The Psalms are noteworthy in Berthelet's choice. Being the longest book of the Bible, their inclusion made the volume more complex, long and expensive, and was clearly paramount for Berthelet and his intended audience.

The layout of the Psalms in Berthelet's Bible owed much to the limited abilities of his print shop. By 1535 European Bibles were printed in a range of sizes, with a variety of aids and addenda, and accompanied by specially commissioned woodblocks, charts and diagrams. This was hardly the case for Berthelet's Bible, which mainly recycled materials from earlier, non-biblical, prints. The Psalms, like other books of the Bible, are presented in two thick textual columns in Gothic type (or Black Letter), with little marginal annotations or additional apparatus. Each verse begins on a new line, starting with a minor capital; the Psalms are numbered and the superscriptions signalled-out, written in Roman type (used in other biblical books for the scant marginal references). This spans the entire length of Berthelet's technological capacities. However, it sufficed to create a layout similar to LMBs and Wycliffite Bibles alike. By using a different typeface for the superscriptions, Berthelet replicated the rubrication of these texts in earlier manuscripts and incunabula. The superscriptions are presented as a distinct textual component. Identifying the Psalms by their incipits was eased by using three-line initials for each chapter, directing one's attention to its opening words and tying-in with current knowledge of the Psalms. Combined with identification of chapter numbers, it reflects Wycliffite Bibles and Continental prints in presenting two parallel systems of retrieval. Readers' annotations reveal that these books were indeed used by diverse audiences - by scholars and exegetes, as well as in church services.

In the very same year, the first complete Bible in English was printed on the Continent. Unlike Berthelet's Bible, its novelty and reformed ideology have attracted considerable scholarly attention. ${ }^{32}$ Compiled by Miles Coverdale, it was

32 RSTC§2063. For scholarship see: Blayney, Stationers' Company, 344-51; S.L. Greenslade, The Coverdale Bible, 1535 (Folkestone: Wm. Dawson \& Sons, 1975); James Frederic Mozley, Coverdale and His Bibles (London: Lutterworth Press, 1953); Gwendolyn Verbraak, "William Tyndale and the Clandestine Book Trade: A Bibliographical Quest for the Printers of Tyndale's New 
based on Luther's German translation, as well as the Vulgate, rather than the original Hebrew and Greek. The circumstances of its creation are encoded in the layout of the Psalms. Much like the earliest strata of the Wycliffite Bible, Coverdale presented the Psalms in a way similar to other biblical texts. Like other biblical books the Psalms are numbered and their number is the sole means of identification, appearing on the heading alongside a running title. The superscriptions are modified into generic identifier of speaker, and merged with the Psalm number into a Psalm title (e.g. The II. A Psalme of Dauid; The XLVI. A Psalme for the children to Corah). As any other biblical text, the Psalms are subjected to an alphabetical sub-division and composed in continuous textual blocks with verses distinguished only by short spaces. The Psalms' Latin incipit are omitted, drawing the Bible away from Latin Psalmody, as well as from earlier Latin and English Bibles. Coverdale's list of corrections (pt 3, fol. 52r) indeed refers to the Psalms according to their numerical value ("In the Psalter. | Upon the xxxv. leaf, the second side, in the cxxxvi. psalm, the second verse [...]”).

Coverdale's engagement with the Psalms was multifaceted. Much like his Goostly psalmes and spirituall songes, ${ }^{33}$ published possibly the very same year, Coverdale's Bible contained no reference to Latin psalmody, rejecting the way the Psalms had been known and recalled by laity and clergy for centuries. This reflected Coverdale's isolated position on the Continent. It was also the work of a Church reformer, wishing to mould a new understanding of the Bible. Coverdale's knowledge of Latin Psalmody from his past as an Augustinian canon cannot be doubted. His Psalter, however, followed that of Luther, whose 1534 Bible (Coverdale's role model) likewise omitted all Latin incipits. For Coverdale the Psalms were to serve as a conduit of personal devotion. This is made clear in his prologue (Unto the Christen reader, sig. w.vi].r), as well as in an interpretative note at the end of the Psalms: "In the Psalter this word sela comes very often. And (after the mind of the interpreters) it is as much to say as, always, continually, for ever, forsooth, verily, a lifting up of the voice, or to make a pause and earnestly to consider, and to ponder the sentence” (pt 3, fol. 37v). This note encapsulates the differing strands of understanding the Psalms: exegetical, performative, and meditative. It is the latter, however, that was key to Coverdale's Psalms.

The layout of Coverdale's Bible was quickly transformed, attesting to the turmoil of the English Church in the last decade of Henry's reign and the reigns

Testament," in Infant Milk or Hardy Nourishment? The Bible for Lay People and Theologians in the Early Modern Period, ed. W. Francois and A. A. den Hollander (Leuven: Peeters, 2009): 167-89. 33 RSTC $\$ 5892$. 
of his offspring. Coverdale's 1535 Bible was created with royal approval in mind. This is evident in its title page, depicting the majestic Henry distributing Bibles, en-par with biblical monarchs. ${ }^{34}$ When the Royal approval became a reality, production quickly changed. James Nicholson of Southwark printed anew its preliminary leaves, sidelining its association with Luther and inserting a dedication to Henry (sig.. .ii.r-iiii.r), which made explicit the appeal of the Bible to the monarch. This prefaced the quires printed abroad, with the abovementioned Psalm layout. While scholars typically focus on the first edition, the Psalms' layout did not remain unchanged as the Bible was reprinted. In all subsequent editions of the Coverdale Bible printed in England, the Psalms underwent further transformations. ${ }^{35}$ The most important of these was the re-integration of the Psalms' Latin incipits, moving these books further away from Coverdale's reformed ideals and closer to English audience and common means of navigating the Psalter.

Coverdale remained a major actor in the production of English Bibles. The landscape of the Bible in England was now transforming on a much grander scale. Up until then, the vast majority of parish churches in England did not have a full Bible, nor were they required to. ${ }^{36}$ Thomas Cromwell $(+1540)$, Henry’s chief minister and royal vicegerent, or vicar-general, was affiliated with the reformed cause, and strongly supported the dissemination of English Bibles. In August 1536 he mandated that every parish church was to have a Bible. ${ }^{37}$ This injunction, reaffirmed in subsequent years, had led to the creation of a new Bible on a national scale, commonly known as the Great Bible. Cromwell lent his considerable support for the project, while Coverdale was to amend the translation. Royal approval was paramount to the project, and, as explored by Tatiana String, the title page to the Great Bible distilled Henry's view of a national Bible: A majestic Henry is portrayed disseminating Bibles to priests and nobles (assisted

34 Tatiana C. String, Art and Communication in the Reign of Henry VIII (Aldershot: Ashgate, 2008), 88-91.

351537 RSTC $22064 ; 1537$ RSTC\$2065; 1550 RSTC\$2080; 1553 RSTC $\$ 2090$

36 Poleg, Approaching the Bible, 67-69.

37 At first a Latin and English Bible: Walter Howard Frere and William McClure Kennedy, eds., Visitation Articles and Injunctions of the Period of the Reformation. Vol. 2: 1536-1558, Alcuin Club Collections (London: Longmans, Green, 1910), 9. In 1538 this was modified to an English Bible alone: Paul L. Hughes and James F. Larkin, eds., Tudor Royal Proclamations: Vol. 1, the Early Tudors, 1485-1553 (New Haven: Yale University Press,1964), 296-98; For a reappraisal of the time of the injunctions: Paul Ayris, "Reformation in Action: The Implementation of Reform in the Dioceses of England," Reformation \& Renaissance Review: Journal of the Society for Reformation Studies 5 (2003): 27-53; refuted by Richard Rex, Henry VIII and the English Reformation, 2nd ed., British History in Perspective (Basingstoke: Palgrave Macmillan, 2006), 190-91, n. 28. 
by Cromwell and Thomas Cranmer [†1556], Archbishop of Canterbury), with the population at the bottom of the page calling 'Long live the King, ${ }^{38}$ This reflected the Epistle of Berthelet's 1535 Bible, as well as the title page of Coverdale's Bible. The Great Bible, however, surpassed all earlier English Bibles in its materiality, printed on high-grade paper in royal folio.

The Great Bible ushered in an era of English Bibles and English psalmody. Its size, alongside the omission of most marginal annotations, led to a clear and spacious layout (Fig. 5). The Psalms are introduced by the Psalm number, a Latin incipit, and the biblical superscription. A three- or four-line capital letter marks the beginning of the text of the Psalm itself. Typographically, the Latin incipit is the most distinct feature of the Psalms' layout, printed in Roman capitals on the background of Black Letter. Unlike Coverdale's or the Wycliffite Bible, this was not meant to be a reformed Bible, but rather a continuation of past practices. It was to facilitate - at least in theory - the liturgy in every parish church, as well as in cathedrals and collegiate churches (where liturgy was still performed in Latin). It linked the English Psalms, new to many, with past knowledge of the Psalms, which was still predominantly oral and performative. ${ }^{39}$ This emphasis is also reflected in the liturgical addenda to the Bible, containing a table of liturgical lessons according to the Use of Sarum, similar to that found in many Wycliffite Bibles. The Great Bible was printed in seven successive editions (the last in December 1541), with minimal alterations to the layout of the Psalms or its liturgical addendum.

The layout of the Great Bible contains traces of a controversy surrounding its inception and influencing its reception. Manicules, or pointing hands, appear throughout the biblical text (Fig. 5). ${ }^{40}$ The Prologue to the Bible (sig. *.[v.]v) explicates that these were meant to be accompanied by explanatory notes, which, unfortunately, had not been printed due to lack of time and the need for approval. Correspondence between members of the production team reveals the notes to be the most controversial element within the Bible, with Coverdale assuring Cromwell repeatedly of their value and un-contentious nature. Cromwell, the patron of the Great Bible, supported the type of lay access to Scripture that was facilitated by such annotations. His hesitation reveals other forces at play. The annotations never saw the light of day, and in subsequent editions the manicules themselves were removed, furthering the need for clerical mediation. Henry's unease with lay access to Scripture quickly came to the fore. In 1543 Henry's Act

38 String, Art and Communication, 96-98.

39 As the Great Bible adopted the Hebrew numbering of the Psalms, which differed from that of the Vulgate, the Latin incipits were even more important as means of linking the Psalms with past knowledge.

40 On the manicules to the Great Bible see Poleg, A Material History of the Bible, pp. 133-8. 


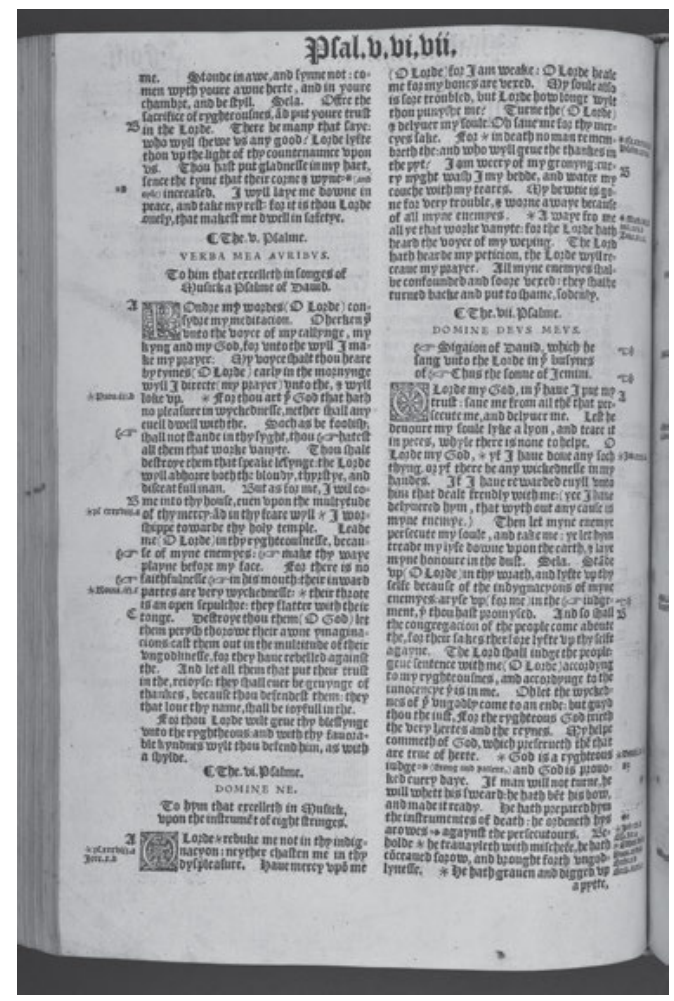

Fig. 5: Great Bible Psalms (The Byble in Englyshe [...] (London: Rychard Grafton and Edward Whitchurch, April 1539), pt 3 fol. $2 v$. Edinburgh University Library Special Collections.

for the Advancement of True Religion joined with the King's Book to curb unrestricted lay access to Scripture, forbidding private and public reading by women of the lower classes, artificers, prentices, journeymen, yoemen and under. ${ }^{41}$ As the layout of the Psalter in the Great Bible reveals, it was a book caught between reformed ideals and a more hesitant monarch.

41 The Statutes of the Realm, Printed by Command of His Majesty King George the Third, in' Pursuance of an Address of the House of Commons of Great Britain from Original Records and Authentic Manuscripts. (London: Eyre and Strahan, 1817; reprint, 1963), 3:894-97. For the original draft, analysis and reappraisal see Blayney, Stationers' Company, 550-55. For the King's Book: Henry VIII, “The King's Book: Or, a Necessary Doctrine and Erudition for Any Christian Man, 1543," in Church Historical Society New series, ed. T.A. Lacey (London: Society for Promoting Christian Knowledge, 1932): 5-6. For analysis: Alec Ryrie, The Gospel and Henry VIII: Evangelicals in the Early English Reformation, Cambridge Studies in Early Modern British History (Cambridge: Cambridge University Press, 2003), 44-54; Richard Rex, "The Crisis of Obedience: God's Word and Henry’s Reformation,” The Historical Journal 39 (1996): 863-94. As demonstrated by Ryrie (The Gospel and Henry VIII: Evangelicals in the Early English Reformation, 49-50), there is little to suggest the law had ever been enforced. 


\section{The Bibles of Edward VI and Elizabeth I}

No other Bible was printed for the remainder of Henry's reign. Following his death in 1547 and the accession of the young Edward VI, reformers were once more at the helm. During Edward's short reign, Bible printing proliferated, with eleven full Bibles printed in diverse formats and by different printers. ${ }^{42}$ Liturgy also underwent a major transformation. Thomas Cranmer, the Archbishop of Canterbury, was able to implement his plans for reforming the liturgy, which had been foiled under the previous reign. This led to the introduction of the Book of Common Prayer (BoCP), printed in 1549 and in a revised edition in $1552 .{ }^{43}$ It was meant to replace all other liturgical books by providing a uniform and simplified liturgy across the realm. The Bible was to serve as the backbone of the new liturgy, with the entire Bible read throughout the year, the New Testament three times, and the Psalter chanted every month. Cranmer made this explicit in the Preface to the book, negating the medieval past in advocating a simplified, and more biblically oriented, worship:

the ancient fathers had devised the psalms into seven portions: whereof every one was called a nocturne: now of late time a few of them have been daily said (and oft repeated) and the rest utterly omitted. Moreover, the number \& hardness of the rules called the pie [Ordinale], and the manifold changings of the service, was the cause, that to turn the book only, was so hard and intricate a matter, that many times, there was more business to find out what should be read, then to read it when it was found out. [sig. A.ii.r]

In the book itself, 'THE ORDRE how the Psalter is appointed to be read' (sig. A.iii.v-A.iiii.r) elucidates the way of reading the Psalms in monthly cycles, including how to manage longer or shorter months. Intentionally and explicitly, it breaks away with common Psalmody and Psalms' mnemonics. The seven-fold division of the Psalms, which facilitated chant in monasteries and cathedrals, and depicted in Latin and English manuscripts alike, is put aside in favour of a simplified monthly cycle. The Latin incipits are once more removed. Like other Church reformers, from the earlier Wycliffite Bibles to Coverdale's Bible, Cranmer

42 For a study of these Bibles see: Poleg, A Material History of the Bible, esp. ch. 5, "Into Fast Forward: The Bibles of Edward VI".

43 RSTC II:87-90; “The Book of Common Prayer: The Texts of 1549, 1559, and 1662,” ed. Brian Cummings (Oxford: Oxford University Press, 2011); Bryan Spinks, "The Bible in Liturgy and Worship, C. 1500-1750," in The New Cambridge History of the Bible: Volume 3: From 1450 to 1750, ed. Euan Cameron (Cambridge: Cambridge University Press, 2016): 563-78; Aude de Mézerac-Zanetti, "A Reappraisal of Liturgical Continuity in the Mid-Sixteenth Century: Henrician Innovations and the First Books of Common Prayer,” Revue française de civilisation britannique 22, no. 1 (2017), http://rfcb.revues.org/1218. 
did away with the common way the Psalms were retained in the memory of priests and the laity. This extended also to the numbering of the Psalms. Akin to Continental Reformers, the BoCP follows the numbering of the Great Bible, and hence is incompatible with the Vulgate and its differing numbering. Cranmer, however, was unable to escape past knowledge of the Psalter altogether. Within the book itself, Psalms and hymns are identified by their Latin incipit. Thus, for example, in Matins (fol. ii.r) it is noted that "After the first lesson shall follow Te deus laudamus in English, daily throughout the year, except in Lent, all the which time in the place of Te deum shalbe used Benedicite omnis opera Domini Domino, in English as follows [...]”.

The ideals of reform were likewise not fully embraced by printers, and the layout of Bibles from the reign often incorporates more traditional means of identifying the Psalms. This fluctuated between printers. Bibles printed by new printers typically omit the Latin incipits, while those printed abroad, or by Whitchurch or Grafton (the merchants behind the printing of the Great Bible), preface the Psalms with the Latin incipits. ${ }^{44}$ The last Bible printed in the reign of Edward reveals that Latin incipits were not seen as opposed to reformed liturgy, but rather as complementing it. This innovative Bible was printed by Richard Grafton in 1553, most likely after Edward had been taken ill. ${ }^{45}$ It was the smallest singlevolume English Bible printed hitherto, and the strongest amalgamation between biblical layout and the new liturgy. Marginal notes throughout the Bible identify the time for each biblical reading, following the sequence of the BoCP. In the Psalter, the notes identify the time of the month and morning or evening prayer, when the Psalms were to be read. Thus, as can be seen in Fig. 6, the First Psalm is linked to the first day at matins; Psalm 6 at evensong; Psalm 9 to the second day at matins; and so on. This, however, was accompanied by the integration of the Latin incipits. Alongside the Psalm number (by now an indispensable means of identifying the Psalm, facilitating the monthly cycle of Psalmody) the Latin incipit is integrated into the title preceding each Psalm. The biblical superscriptions are omitted altogether, attesting to the liturgical nature of the Psalter, if not to a rushed production.

Grafton's Bible constitutes the zenith of the link between Bible and new liturgy. It also marks its temporary end. The death of Edward and the Accession of Mary had moved the realm away from reform. Liturgy reverted back to Latin,

44 Including the incipits are Incipits: RSTC§2079; RSTC§2080; RSTC§2081; RSTC§2019; RSTC§2092; Omitting the incipits are the Bibles printed by John Day (with William Seres) and William Hill (with Thomas Raynolds): RSTC§2077; RSTC§2078; RSTC§2083-6; RSTC§2088. The exception is RSTC\$2089, printed by Hill and containing the Latin incipits, as well as the BoCP. 45 RSTC§2092. 


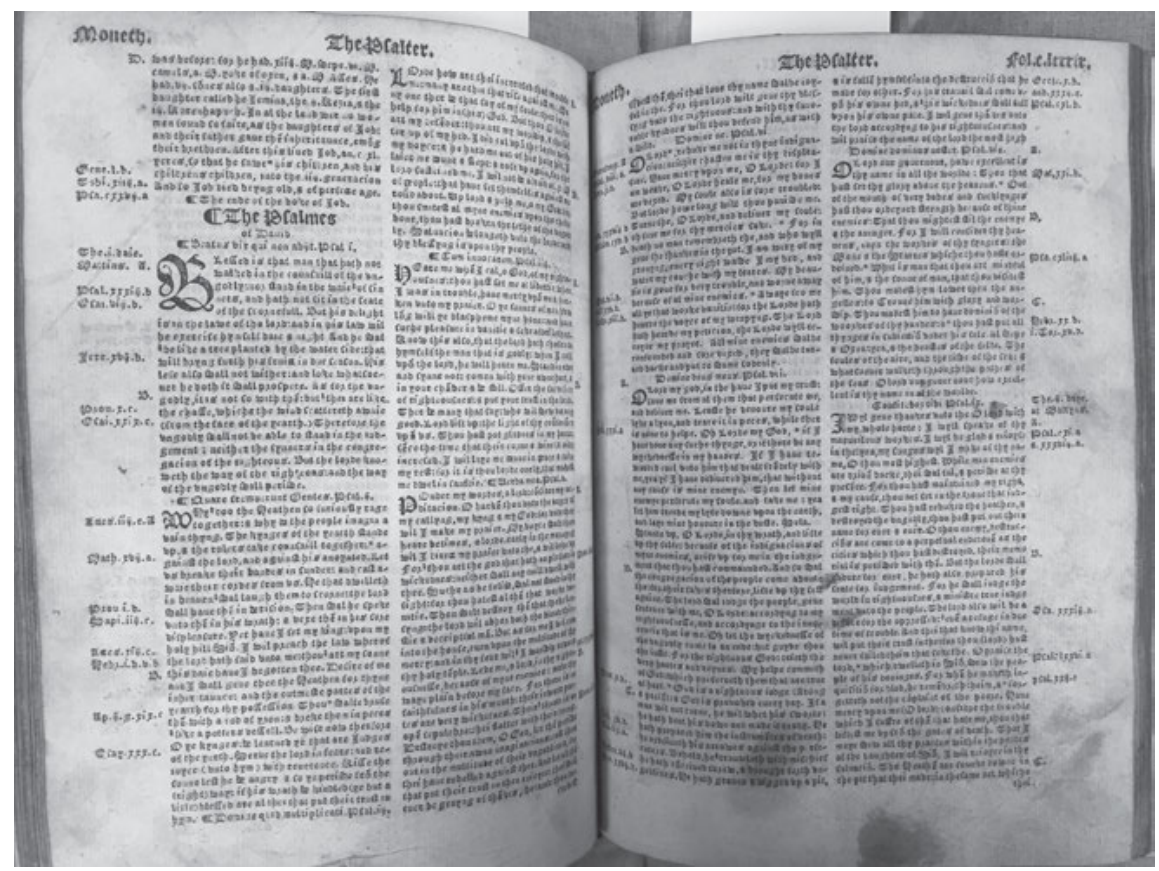

Fig. 6: Grafton 1535 Psalms (The Bible in Englishe [...] (London: Richard Grafton, 1553), fols $188 \mathrm{v}$-189r). Reproduced by kind permission of the Syndics of Cambridge University Library.

and reformers fled the country to find refuge in Protestant strongholds. Some settled among the Calvinists of Geneva, where a new edition of the Bible was prepared, tapping into cutting-edge Continental theology and technology. This resulted in arguably the most influential Bible of early modern England. Created by a team of scholars and translators (including Coverdale), it was published in 1560, already after Elizabeth I's accession. The Geneva Bible became an overwhelming success and was printed in c.140 editions, surviving even the introduction of the King James Version in $1611{ }^{46}$ The first edition of the Geneva Bible

46 RSTC\$2093. For facsimile and introduction see: Lloyd E. Berry, ed., The Geneva Bible, a Facsimile of the 1560 Edition (Madison: University of Wisconsin Press, 1969); Maurice S. Betteridge, "The Bitter Notes: The Geneva Bible and Its Annotations," The Sixteenth Century Journal 14 (1983): 41-62. An in-depth examination of subsequent prints, editions, and reception are: Ian Green, Print and Protestantism in Early Modern England (Oxford: Oxford University Press, 2000), 42-100, esp. ch. 2, "English Bibles and Their Owners"; Femke Molekamp, “Using a Collection to Discover Reading Practices: The British Library Geneva Bibles and a History of Their Early Modern Readers,” The Electronic British Library Journal (2006); Molekamp, “Genevan Legacies: The Making of the English Geneva Bible," in The Oxford Handbook of the Bible in England, C. 
is surprisingly modest. Unlike Berthelet's 1535 Bible, this was matter of choice rather than necessity. Printed in quarto on thin paper kept costs down, befitting the production team's ideology of disseminating the Bible far and wide across the social spectrum.

The Geneva Bible emulated Continental models to become the first English Bible printed in Roman type, and the first to integrate verse division (Fig. 7). Applying verse numbers across the Bible diminished one of the unique features of the Psalms' layout, as all books of the Bible were now written in identifiable lines of meaning. Unlike the Psalms' layout in earlier Bibles, the new division was not made to facilitate or mirror liturgical performance. Rather, the address to the reader [sig. ${ }^{\star}{ }^{\star}$.iiii.r-v] depicted this new division as "most profitable for memory," and useful for biblical study. Once more, typically of reformed Bibles, the Psalms' layout took the form of any other biblical book. Extensive marginal annotations provided readers with commentary on the biblical text. The Psalms are preceded by a short summary (or argument) and the biblical superscription. Both are printed in italic typeface, which had a dual effect: detaching the superscription from the text of the Psalm, while equating it with the argument, which emulates the spirit of the superscriptions by connecting the Psalms to events from the life of David or the tenets of Christian faith. ${ }^{47}$ Many arguments reflect the experience of the community of exiles in Geneva, and its memories of persecution. Thus, for example, the argument to Psalm 4 alludes to Saul's persecution of David; the note to the superscription of Psalm 29/30 refers to the dedication of David's house, "After that Absalóm had polluted it with most filthy fornication." Other arguments and notes seamlessly embed theological stands. The note to the superscription of Psalm 31/32 identifies David's instructions to "the free remission of sins, which is the chiefest point of our faith," with subsequent notes expounding on the reformed ideal of Justification by Faith. The note to Psalm 44/45:17 facilitates a clear Christological reading ("This must only be referred to Christ and not to Salomón”). An additional interpretative layer is incorporated into the running titles, which provide succinct allegorical interpretations, as, for example, in the title to Psalm 55/6 The tears of the Saints or 74/5 The Church afflicted prays (both reflecting Genevan perceptions). Much like

1530-1700, ed. Kevin Killeen, Helen Smith, and Rachel Willie (Oxford: Oxford University Press, 2015): 38-53; Thomas Fulton, “Toward a New Cultural History of the Geneva Bible," Journal of Medieval and Early Modern Studies 47 (2017): 487-516.

47 Molekamp, “Genevan Legacies”; Erica Longfellow, "Inwardness and English Bible Translations," in The Oxford Handbook of the Bible in England, C. 1530-1700, ed. Kevin Killeen, Helen Smith, and Rachel Willie (Oxford: Oxford University Press, 2015): 626-39; Fulton, "Toward a New Cultural History of the Geneva Bible". 


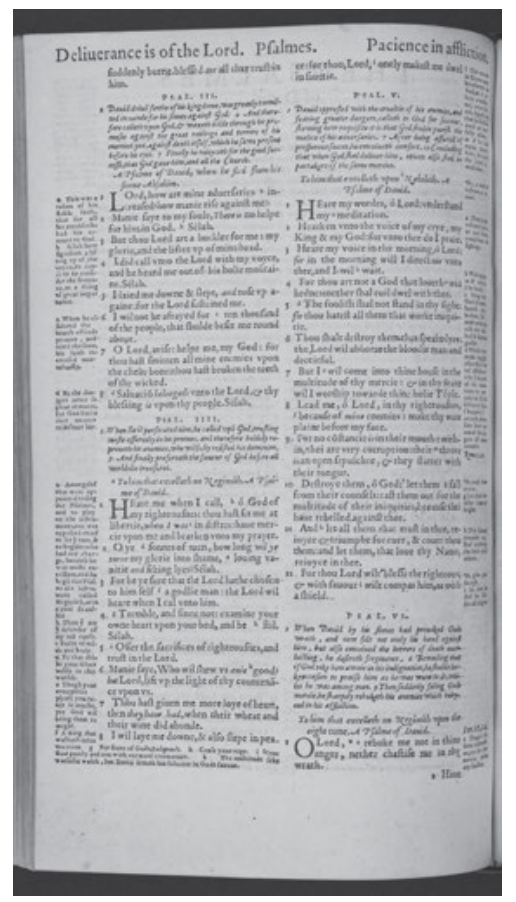

Fig. 7: Geneva Bible Psalms (The Bible and Holy Scriptures [...] (Geneva: Rouland Hall, 1560), fol. 235v). Edinburgh University Library Special Collections.

the glosses to the Wycliffite Bible, arguments and titles are presented as a form of biblical summary, rendering the editors' interpretation inseparable from the literal sense of the biblical text.

Given the reformed nature of the Geneva community, it is hardly a surprise that Latin incipits do not appear in the Geneva Bible. The Psalms are detached not only from Latin Psalmody, but from performance more widely. The introduction to the Psalter lacks any reference to their performance, but only praises their meditative and edifying value. The reader is asked to "seek" and "know", rather than chant. This is reiterated in the argument of the first Psalm, which explicitly sees the Psalter's goal "to exhort all godly men to study, and meditate the heavenly wisdom" (fol. 235.r). No chanting nor performance, but study and devotion. One should not assume that the Genevan community shied away from chanting the Psalms. Quite the opposite. It encouraged a nearly constant Psalmody, but not in their Bibles. The Genevan community embraced a new type of Psalmody, first created by Thomas Sternhold ( +1549$)$ with secular tunes to facilitate personal devotion during the reign of Edward VI. It was then revised, following Continental tunes and practices by John Hopkins (†1570), to create a metrical Psalter, which 
became the cornerstone of Genevan congregational Psalmody. ${ }^{48}$ As demonstrated by Quitslund, the metrical Psalter influenced the appearance of the Psalms in the Geneva Bible, which replicated most of the former's arguments, as well as incorporating some of its notes and texts. ${ }^{49}$ However, unlike the Geneva Bible, the metrical Psalter was more attuned to performance. The metrical Psalter printed in 1556 in Geneva (RSTC\$16561) omits the biblical superscriptions, while incorporating Latin incipit, argument, and musical notations. The same layout spread beyond the Genevan community. It was often employed in The Whole Book of Psalmes (known also as Sternhold and Hopkins), which became one of the most popular books in early modern England. The Geneva congregation thus employed two different Psalters for two different purposes: the metrical Psalter for liturgy and private Psalmody, and the Psalms in the Geneva Bible for study and meditation.

The Geneva Bible, despite its popularity, was not printed in England for almost two decades. A more conservative party, led by Archbishop Parker (†1575), opposed its reformed origins and some of its annotations. In its stead, Parker initiated a new Bible: The Bishops' Bible of $1568 .{ }^{50}$ A royal folio, its printing was meticulous and of the highest quality, a world apart from the faded ink and lower-grade paper of the Geneva Bible. Unlike the Geneva Bible, The Bishops' Bible was created with performance in mind. It followed the Bibles of Edward VI's reign, and was meant to fill the need of re-installing Bibles into churches, following Mary's reign. It is therefore equipped with a plethora of liturgical apparatus: a table of lessons, the order of Psalms in morning and evening prayers, as well as an almanac and an extended calendar, all laboriously printed in red and black ink. Its Psalter (Fig. 8), newly translated from the Hebrew, replicates the liturgical layout of Grafton's 1553 Bible, with a title indicating the day and the prayer, accompanied by a marginal note and a major illuminated initial (6-10

48 Beth Quitslund, The Reformation in Rhyme: Sternhold, Hopkins and the English Metrical Psalter, 1547-1603, St Andrews Studies in Reformation History (Aldershot: Ashgate, 2008); Ian Green, "Hearing and Reading: Disseminating Bible Knowledge and Fostering Bible Understanding in Early Modern England," in The Oxford Handbook of the Bible in England, C. 1530-1700, ed. Kevin Killeen, Helen Smith, and Rachel Willie (Oxford: Oxford University Press, 2015): 272-86; Nicholas Temperley, “'All Skillful Praises Sing': How Congregations Sang the Psalms in Early Modern England,” Renaissance Studies 29 (2015): 531-53; Green, Print and Protestantism, ch. 9 , "Mystery of Metrical Psalm".

49 Quitslund, The Reformation in Rhyme, 190-92.

50 RSTC\$2099. Relatively little has been written on this Bible: Margaret Aston, “The Bishops' Bible Illustrations," in The Church and the Arts, ed. Diana Wood (Oxford: Blackwell, 1992): 267-85; C. Clair, “The Bishops' Bible 1568," Gutenberg Jahrbuch (1962): 287-90; Green, Print and Protestantism; A recent monograph adds little new information: Jack P. Lewis, The Day after Domesday: The Making of the Bishops' Bible (Eugene: Wipf \& Stock, 2016). 


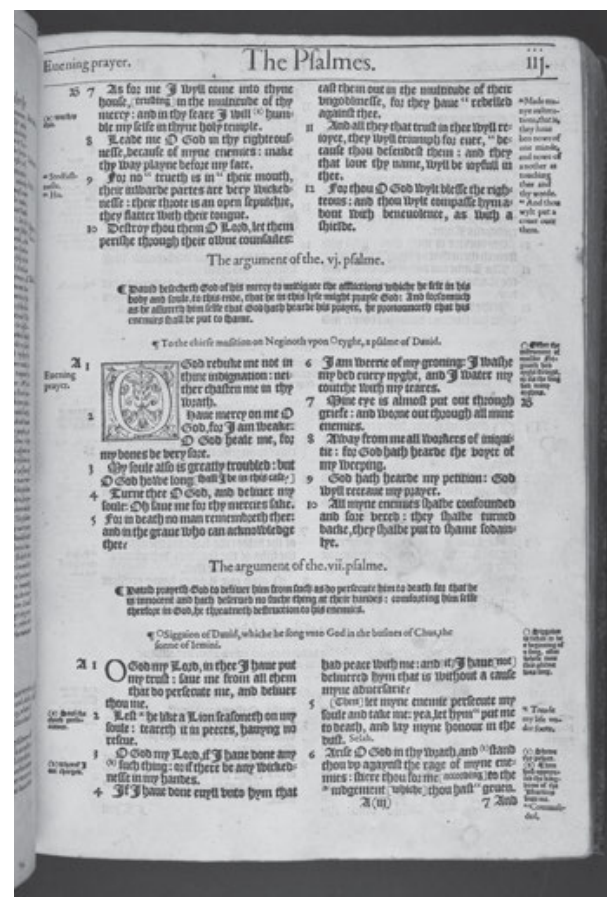

Fig. 8: Bishops' Bible Psalms (The. holie. Bible [London: Richarde lugge, 1568], pt 3 p.3). Edinburgh University Library Special Collections.

lines, as distinct from the 2-3 lines medium, non-illuminated, initial for other Psalms), which identifies the beginning of each section. However, much like the Geneva Bible, old ways of knowing the Psalter are omitted: The Psalms reproduce the Geneva verse-numbering, and no Latin incipits are attached to individual Psalms. ${ }^{51}$ The Psalms are preceded by an argument and by the superscription, grounding them in biblical history and Christian faith.

The Geneva and Bishops' Bibles are often examined as opposed to one another, embodying the rift within the Elizabethan Church. They could not be more different in appearance - one a small quarto, the other a royal folio that surpassed even the Great Bible in size. The Psalters in their first editions share, however, important similarities. Both broke away from past knowledge and Psalmody: They newly translated the Psalms from the Hebrew, and omitted, by and large, the Psalms' Latin incipits. In both Bibles, however, these transformations proved short-lived, already modified in the second edition of both Bibles printed in England. The second royal folio edition of the Bishops' Bible

51 A brief table at the end of the Psalter (Numerus secundum Hebreos, pt 3 fol. 48v) links Latin incipit with Psalm number. 


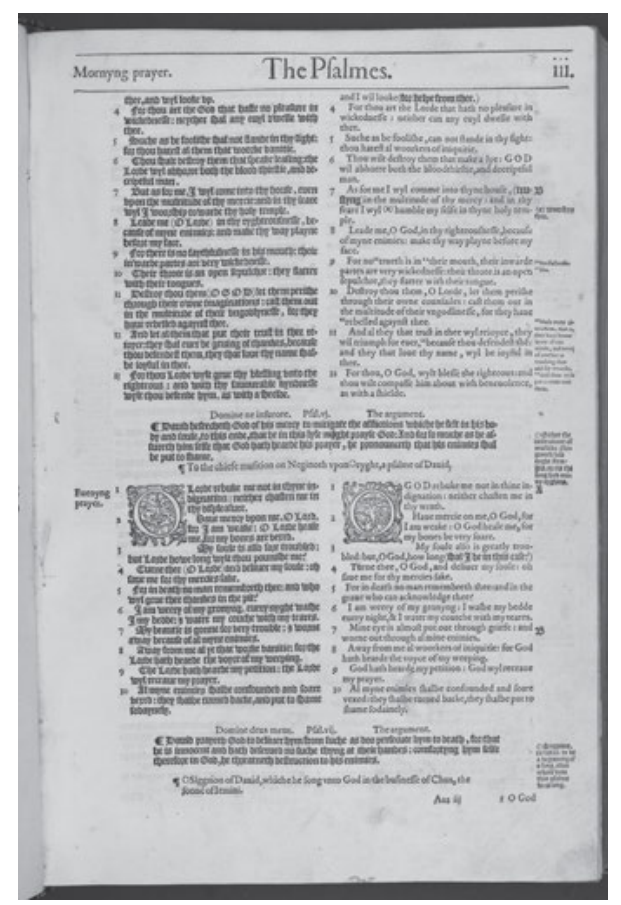

Fig. 9: Bishops' 1572 Psalms (The. holie. Bible [London: Richarde lugge, 1572], pt 3 p.3). Edinburgh University Library Special Collections.

bears a strong resemblance to the second edition of the Geneva Bible printed in England following Parker's death. ${ }^{52}$ As could be seen in the Psalter in the Bishops' 1572 edition (Fig. 9), this was an attempt to convey the two translations simultaneously, presenting Coverdale's Psalms alongside the newly translated ones. ${ }^{53}$ Distinct typographical means separate the two texts. The 'old' Psalter is printed in Black Letter in the inner part, while the 'new' version in Roman type on the outer part. The Psalm is preceded by argument, number, and superscription, written across the two columns. While above the 'new' version appears the title of the argument, the 'old' version is preceded by the Latin incipit, adding to its liturgical applicability. The choice of typeface is not accidental. Black Letter was typically employed in the BoCP, creating not only a textual but also a visual allusion between text and performance; Roman type, innovative to sixteenth-century readers, likewise indicated the novelty of the new translation. $^{54}$

52 RSTC§2107; RSTC§2123.

53 This mirrors the dual-Psalters of the High Middle Ages, which presented in parallel columns Jerome's distinct translations.

54 Green, Print and Protestantism, 61-65; Molekamp, “Using a Collection”. 
The dual Psalter enabled the old and the new to share the same space. Its use of two typefaces in two columns, with materials printed across columns in both Roman type and Black Letter, was an impressive feat. It would have proved challenging even for the most accomplished printer and was quickly abandoned. Subsequent editions set the Geneva and Bishops' Bibles once more on separate tracks. After $1573,{ }^{55}$ editions of the Bishops' Bible contained a single translation that used in the BoCP. The Psalms were thus printed in an inferior translation, but the one used daily in churches. These editions brought the Psalms' performance centre-stage, with a lack of arguments, summaries or notes, a complete removal of superscriptions and the full reintegration of the Latin incipits. Some of these Bibles, such as the 1573 quarto edition (RSTC\$2108), are also prefaced by the entire BoCP, enhancing their liturgical applicability.

Subsequent editions of the Geneva Bible followed a similar trajectory, which embodies the influence of the liturgy in a process that was accelerated once printing commenced in England. Still in Geneva, metrical Psalms were inserted alongside other hymns at the end of a quarto edition of $c .1569$ (RSCT§2106). Their translation did not follow the BoCP, but rather that of the metrical Psalter, which grew in popularity in Geneva and England. Two years after printing of the Geneva Bible commenced in England, the above-mentioned dual Psalter was published, but was quickly abandoned. The first quarto edition of the Geneva Bible printed in London in 1579 (RSTC§2126) embraced a new strategy of great longevity. It follows previous editions in presenting a single Psalter between Job and Proverbs - that of the Geneva version with its arguments, superscriptions, headings and annotations. However, a very different Psalter is provided at the beginning of the book. Accompanied by the liturgical apparatus typical of the Bishops' Bible, it encompasses the entire BoCP, alongside a full Psalter. Its Psalms were of the Great Bible's translation, without arguments or superscriptions but preceded by their Latin incipit; rubrics and titles connected the Psalms to their performance in the monthly cycle. Thus, avoiding the complex printing of a parallel edition, this solution preserved the newly translated Psalms for meditative and scholarly purposes, while providing a performance-oriented Psalter as well. ${ }^{56}$ The latter's position at the beginning of the volume suggests that it was the liturgical Psalter that served as a first port-of-call. The Geneva Psalms could be located only after leafing through much of the book. This quarto edition was highly influential and replicated in numerous subsequent editions, at times with the Whole Book of Psalmes added at the end of the volume.

55 Apart from the folio edition of 1585, RSTC§2143.

56 This is similar to the modularity of Dutch Books of Hours: Rudy, Piety in Pieces. 


\section{Conclusion}

The evolution of the Psalms' layout over four hundred years reveals a surprisingly constant pattern: a pendulum move between two ways of conceptualising the Psalter. Innovative layouts and new ways of engaging with the Psalms have been introduced to Bibles across the period. The same phenomenon is revealed in the small mendicant sub-group of the 1250s, in the early manuscripts of the Wycliffite Bible and Coverdale's 1535 Bible, as in the Geneva Bible of 1560 and the Bishops' Bible of 1568. In all these Bibles, the layout of the Psalms was made to accord with that of other biblical books, removing the unique, older, and primarily liturgical features of the Psalms' layout. This was often accompanied by the introduction of a new translation. Without exception, in each and every one of these instances, the change was subdued, modified, or completely obliterated. In later manuscripts and subsequent editions new divisions were removed, older translation re-introduced, and liturgical elements re-embedded. These transformations reveal the power of performance and mnemonics. Lay and clerical audiences alike encountered the Psalms through their chanting in the liturgy. The Psalms were intrinsically linked to their Latin incipits (a primary way in which they had been known and recalled throughout the period under investigation), and to a layout that reflected chant and liturgy. And despite the best efforts of innovators and reformers, the Psalms' layout continued to reflect this knowledge.

A material history of the Bible directs our attention to books less frequently explored by scholars of the English Bible. Studies of texts and Reform often highlight first editions as landmarks in the history of the English Bible. The dynamics of layout, however, are better served by tracing the changes these Bibles underwent over time, especially in dialogue with the English market. Most people encountered the Bible through subsequent editions, which often transformed biblical layout and text. These editions assist in presenting a more nuanced view of English religious history. Most Wycliffite Bibles are far from representing their heterodox inception, and subsequent editions of Coverdale's 1535 Bible omit some of its most reformed features. Latin and English emerge in these editions not as opposing forces, but as converging linguistic spheres. Thus, the LMB and the Wycliffite Bible have much in common, as do the Geneva and the Bishops' Bibles.

Innovative layouts were often the work of Church reformers, attempting to mould new ways of engaging with the Bible. Scholars have indeed attempted to trace the work and intellectual biographies of reformers such as Wyclif (and his followers), Tyndale, and Coverdale. Subsequent editions and later manuscripts, however, draw our attention to a different power shaping English Bibles and religion. Modifications which went back on theological innovation and embraced popular perceptions were often introduced by printers and stationers. 
Many LMBs and later Wycliffite Bibles were the work of professional (and lay) stationers; Bibles were printed by a handful of merchants. Many of these were devout, with evidence for Lollard scribes, or the reformed affiliation of Grafton and Whitchurch. They also had to accord with market forces, ensuring that their Bibles would sell and repay the huge investment in ink and labour, paper or parchment. The omission of heterodox articles of faith by London stationers producing Wycliffite Bibles in the early fifteenth century, or the side-lining of Luther's influence when Nicolson reprinted the preliminaries of Coverdale's Bible, attest to the way printers and stationers subdued more contentious materials, thus enhancing their appeal to wider markets. More work is needed to trace the commercial elements behind the production of religious texts, but, as is evident from work on seventeenth-century printers, ${ }^{57}$ it has the potential to transform our understanding of English religion.

The period under investigation saw the rise of moveable-type print, religious reform and political upheavals. Through the prism of materiality - and the Psalms' layout in particular - we can identify important continuities: Psalms were known through their Latin incipits long after the introduction of English Bibles, and the layout of early modern Bible owed much to their medieval predecessors. Changes are equally important. In his edition of the BoCP, Brian Cummings addresses the forces opposing the introduction of the new liturgy. ${ }^{58}$ The Bibles of the 1570s reveal how the BoCP's Psalters became a new orthodoxy. More accurate translations, conservative and reformed alike, were put aside in favour of the liturgical Psalms. Performance remained key to the way the Psalms were presented and recalled.

\section{Bibliography}

Aston, Margaret. "The Bishops' Bible Illustrations." In The Church and the Arts, edited by Diana Wood, 267-85. Oxford: Blackwell, 1992.

Ayris, Paul. "Reformation in Action: The Implementation of Reform in the Dioceses of England." Reformation \& Renaissance Review: Journal of the Society for Reformation Studies 5 (2003): 27-53.

Berry, Lloyd E., ed. The Geneva Bible, a Facsimile of the 1560 Edition. Madison: University of Wisconsin Press, 1969.

57 James Doelman, “George Wither, the Stationers Company and the English Psalter," Studies in Philology 90 (1993): 74-82.

58 "The Book of Common Prayer: The Texts of 1549, 1559, and 1662," xvii. 
Betteridge, Maurice S. “The Bitter Notes: The Geneva Bible and Its Annotations.” The Sixteenth Century Journal 14 (1983): 41-62.

Blayney, Peter W.M. The Stationers' Company and the Printers of London 1501-1557. 2 vols. Cambridge: Cambridge University Press, 2013.

“The Book of Common Prayer: The Texts of 1549, 1559, and 1662." Edited by Brian Cummings. Oxford: Oxford University Press, 2011.

Cameron, Euan, ed. The New Cambridge History of the Bible: Volume 3: From 1450 to 1750. New Cambridge History of the Bible. Cambridge: Cambridge University Press, 2016.

Carruthers, Mary. The Book of Memory: A Study of Memory in Medieval Culture. Cambridge Studies in Medieval Literature. Cambridge: Cambridge University Press, 1992.

Clair, C. “The Bishops’ Bible 1568.” Gutenberg Jahrbuch (1962): 287-90.

d'Avray, David. "Printing, Mass Communication and Religious Reformation: The Middle Ages and After." In The Uses of Script and Print, 1300-1700, edited by Julia C. Crick and Alexandra Walsham, 50-70. Cambridge: Cambridge University Press, 2004.

de Mézerac-Zanetti, Aude. "A Reappraisal of Liturgical Continuity in the Mid-Sixteenth Century: Henrician Innovations and the First Books of Common Prayer." Revue française de civilisation britannique, no. 1 (2017), http://rfcb.revues.org/1218.

Dijk, S.J.P. van. “Medieval Terminology and Methods of Psalm Singing.” Musica Disciplina 6 (1952): 7-26.

Doelman, James. “George Wither, the Stationers Company and the English Psalter." Studies in Philology 90 (1993): 74-82.

Dove, Mary, ed. The Earliest Advocates of the English Bible: The Texts of the Medieval Debate. Exeter: University of Exeter Press, 2010.

Dove, Mary. The First English Bible: The Text and Context of the Wycliffite Versions. Cambridge Studies in Medieval Literature 66. Cambridge: Cambridge University Press, 2007.

Duffy, Eamon. Marking the Hours: English People and Their Prayers 1240-1570. New Haven, CT.: Yale University Press, 2006.

Frere, Walter Howard, and William McClure Kennedy, eds. Visitation Articles and Injunctions of the Period of the Reformation. Vol. 2: 1536-1558, Alcuin Club Collections. London: Longmans, Green, 1910.

Fulton, Thomas. "Toward a New Cultural History of the Geneva Bible." Journal of Medieval and Early Modern Studies 47 (2017): 487-516.

Ghosh, Kantik. "The Prologues." In The Wycliffite Bible: Origin, History and Interpretation, edited by Elizabeth Solopova, 162-82. Leiden: Brill, 2016.

Green, lan. "Hearing and Reading: Disseminating Bible Knowledge and Fostering Bible Understanding in Early Modern England." In The Oxford Handbook of the Bible in England, C. 1530-1700, edited by Kevin Killeen, Helen Smith and Rachel Willie, 272-86. Oxford: Oxford University Press, 2015.

Green, Ian. Print and Protestantism in Early Modern England. Oxford: Oxford University Press, 2000. Green, William M. “Hugo of St. Victor: De Tribus Maximis Circumstantiis Gestorum.” Speculum 18 (1943): 484-93.

Greenslade, S.L. The Coverdale Bible, 1535. Folkestone: Wm. Dawson \& Sons, 1975.

Harper, John. The Forms and Orders of Western Liturgy from the Tenth to the Eighteenth Century: A Historical Introduction and Guide for Students and Musicians. Oxford: Clarendon Press, 1991.

Hellinga, Lotte. "Printing." In The Cambridge History of the Book in Britain Volume 3: 1400-1557, edited by Lotte Hellinga and J. B. Trapp, 65-108. Cambridge: Cambridge University Press, 1999. 
Hudson, Anne. The Premature Reformation: Wycliffite Texts and Lollard History. Oxford: Oxford University Press, 1988.

Hudson, Anne, and Elizabeth Solopova. "The Latin Text." In The Wycliffite Bible: Origin, History and Interpretation, edited by Elizabeth Solopova, 107-32. Leiden: Brill, 2016.

Hughes, Paul L., and James F. Larkin, eds. Tudor Royal Proclamations: Vol. 1, the Early Tudors, 1485-1553. New Haven: Yale University Press, 1964.

Kuczynski, Michael P. “Glossing and Glosses.” In The Wycliffite Bible: Origin, History and Interpretation, edited by Elizabeth Solopova, 346-67. Leiden: Brill, 2016.

Lacey, T.A., ed. Henry VIII, “The King's Book: Or, a Necessary Doctrine and Erudition for Any Christian Man, 1543.” In Church Historical Society New series. London: Society for Promoting Christian Knowledge, 1932.

Lewis, Jack P. The Day after Domesday: The Making of the Bishops' Bible. Eugene: Wipf \& Stock, 2016.

Light, Laura. "Thirteenth-Century Pandects and the Liturgy." In Form and Function in the Late Medieval Bible, edited by Eyal Poleg and Laura Light, 185-215. Leiden: Brill, 2013.

Light, Laura. "What Was a Bible For? Liturgical Texts in Thirteenth-Century Franciscan and Dominican Bibles." Lusitania Sacra 34 (2016): 165-82.

Longfellow, Erica. "Inwardness and English Bible Translations." In The Oxford Handbook of the Bible in England, C. 1530-1700, edited by Kevin Killeen, Helen Smith and Rachel Willie, 626-39. Oxford: Oxford University Press, 2015.

McFall, Lesley. "The Evidence for a Logical Arrangement of the Psalter." Westminster Theological Journal 62 (2000): 223-56.

Mirelman, Sam. “Contrafactum in the Ancient near East." In Herausforderungen Und Ziele Der Musikarchäologie : VorträGe Des 5. Symposiums Der Internationalen Studiengruppe Musikarchäologie Im Ethnologischen Museum Der Staatlichen Museen Zu Berlin, 19.-23. September 2006 = Challenges and Objectives in Music Archaeology: Papers from the 5th Symposium of the International Study Group on Music Archaeology at the Ethnological Museum, State Museums Berlin, 19-23 September 2006, edited by A.A. Both, R. Eichmann, E. Hickmann and L. Koch, 99-110. Rahden: M. Leidorf, 2008.

Molekamp, Femke. "Genevan Legacies: The Making of the English Geneva Bible." In The Oxford Handbook of the Bible in England, C. 1530-1700, edited by Kevin Killeen, Helen Smith and Rachel Willie, 38-53. Oxford: Oxford University Press, 2015.

Molekamp, Femke. "Using a Collection to Discover Reading Practices: The British Library Geneva Bibles and a History of Their Early Modern Readers." The Electronic British Library Journal (2006).

Mozley, James Frederic. Coverdale and His Bibles. London: Lutterworth Press, 1953.

Peikola, Matti. “'First Is Writen a Clause of the Bigynnynge Therof': The Table of Lections in Manuscripts of the Wycliffite Bible." In Form and Function in the Late Medieval Bible, edited by Eyal Poleg and Laura Light, 351-78. Leiden: Brill, 2013.

Pettegree, Andrew. "Publishing in Print: Technology and Trade." In The New Cambridge History of the Bible: Volume 3: From 1450 to 1750, edited by Euan Cameron, 159-86. Cambridge: Cambridge University Press, 2016.

Poleg, Eyal. Approaching the Bible in Medieval England. Manchester Medieval Studies. Manchester: Manchester University Press, 2013.

Poleg, Eyal. "The First Bible Printed in England: A Little Known Witness from Late Henrician England.” JEH 67 (2016): 760-80.

Poleg, Eyal. A Material History of the Bible in England, 1200-1553. Oxford: Oxford University Press, 2020. 
Poleg, Eyal. "Wycliffite Bibles as Orthodoxy." In Instructing the Soul, Feeding the Spirit and Awakening the Passion: Cultures of Religious Reading in the Late Middle Ages, edited by Sabrina Corbellini, 71-91. Turnhout: Brepols, 2013.

Poleg, Eyal, and Laura Light, eds. Form and Function in the Late Medieval Bible. WWMW. Leiden: Brill, 2013.

Quitslund, Beth. The Reformation in Rhyme: Sternhold, Hopkins and the English Metrical Psalter, 1547-1603. St Andrews Studies in Reformation History. Aldershot: Ashgate, 2008.

Rex, Richard. “The Crisis of Obedience: God's Word and Henry's Reformation." The Historical Journal 39 (1996): 863-94.

Rex, Richard. Henry VIII and the English Reformation, 2nd ed. British History in Perspective. Basingstoke: Palgrave Macmillan, 2006.

Rudy, Kathryn M. Piety in Pieces: How Medieval Readers Customized Their Manuscripts. Cambridge: Open Book Publishers, 2016.

Ryrie, Alec. The Gospel and Henry VIII: Evangelicals in the Early English Reformation. Cambridge Studies in Early Modern British History. Cambridge: Cambridge University Press, 2003.

Saenger, Paul. "The Impact of the Early Printed Page on the Reading of the Bible." In The Bible as Book: The First Printed Editions, edited by Paul Saenger and Kimberly Van Kampen, 31-51. London: British Library in association with The Scriptorium: Center for Christian Antiquities, 1999.

Salmon, Pierre. Les “Tituli Psalmorum” Des Manuscrits Latins, Collectanea Biblica Latina. Roma: Abbaye Saint-Jérome, 1959.

Solopova, Elizabeth. Latin Liturgical Psalters in the Bodleian Library: A Select Catalogue. Oxford: Bodleian Library, University of Oxford, 2013.

Solopova, Elizabeth. Manuscripts of the Wycliffite Bible in the Bodleian and Oxford College Libraries. Exeter Medieval Texts and Studies. Liverpool: Liverpool University Press, 2016.

Solopova, Elizabeth, ed. The Wycliffite Bible: Origin, History and Interpretation. Medieval and Renaissance Authors and Texts. Leiden: Brill, 2016.

Spinks, Bryan. "The Bible in Liturgy and Worship, C. 1500-1750." In The New Cambridge History of the Bible: Volume 3: From 1450 to 1750, edited by Euan Cameron, 563-78. Cambridge: Cambridge University Press, 2016.

The Statutes of the Realm, Printed by Command of His Majesty King George the Third, in' Pursuance of an Address of the House of Commons of Great Britain from Original Records and Authentic Manuscripts. London: Eyre and Strahan, 1817. Reprint, 1963.

String, Tatiana C. Art and Communication in the Reign of Henry VIII. Aldershot: Ashgate, 2008.

Sutherland, Annie. English Psalms in the Middle Ages, 1300-1450. Oxford: Oxford University Press, 2015.

Sutherland, Annie. “The Wycliffite Psalms.” In The Wycliffite Bible: Origin, History and Interpretation, edited by Elizabeth Solopova, 183-201. Leiden: Brill, 2016.

Temperley, Nicholas. “'All Skillful Praises Sing': How Congregations Sang the Psalms in Early Modern England." Renaissance Studies 29 (2015): 531-53.

Verbraak, Gwendolyn. "William Coverdale and the Clandestine Book Trade: A Bibliographical Quest for the Printers of Tyndale's New Testament.” In Infant Milk or Hardy Nourishment? The Bible for Lay People and Theologians in the Early Modern Period, edited by W. Francois and A.A. den Hollander, 167-89. Leuven: Peeters, 2009.

Victor, Hugh of St. "The Three Best Memory Aids for Learning History." In The Medieval Craft of Memory: An Anthology of Texts and Pictures, edited by Mary Carruthers and Jan M. Ziolkowski, 32-40. Philadelphia, 2002. 
